\title{
PENYELESAIAN KONFLIK AKIBAT PERJANJIAN NOMINEE DALAM PERSPEKTIF ADR
}

\section{Dedy Arya Dirawan}

Fakultas Hukum Universitas Udayana, E-mail: dedyarya27@yahoo.com

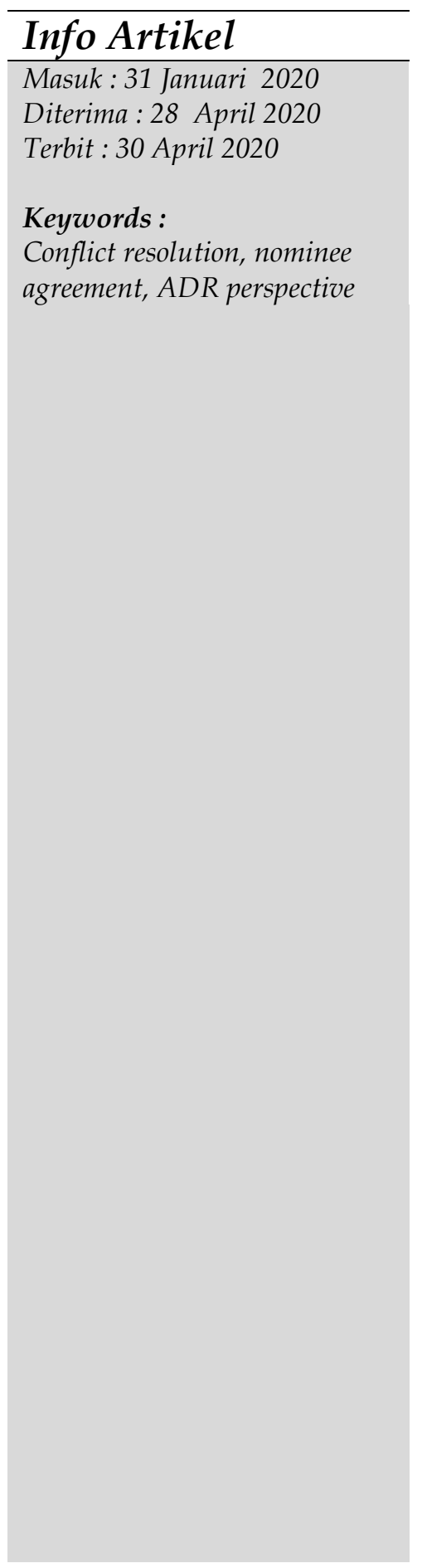

Abstract
Indonesia as an archipelagic country whose
natural wealth has been recognized by the
international world is very attractive to many tourists
(foreign nationals). Various kinds of goals of
foreigners when conducting their activities in
Indonesia, encourage the desire of foreigners to have a
place to live in Indonesia. Foreigners who choose to
live in Indonesia can have a positive impact on
economic development in Indonesia, one of which is by
investing in Indonesia.
The expected goal of this research is to find out
how to resolve conflicts due to nominee agreements in
the perspective of Alternative Dispute Resolution
called (ADR) and to understand how the legal force of
conflict resolution due to nominee agreements through
mediation for the parties to the dispute.
This study deals with the resolution of land
rights disputes due to nominee agreements between
Indonesian Citizens and Foreign Citizens through
mediation in the ADR perspective. This type of
research used in research is to use normative legal
research that is more referring to legal norms
contained in legislation, government regulations,
LoGA, Article 58 of Law No. 48 of 2009, and Law no.




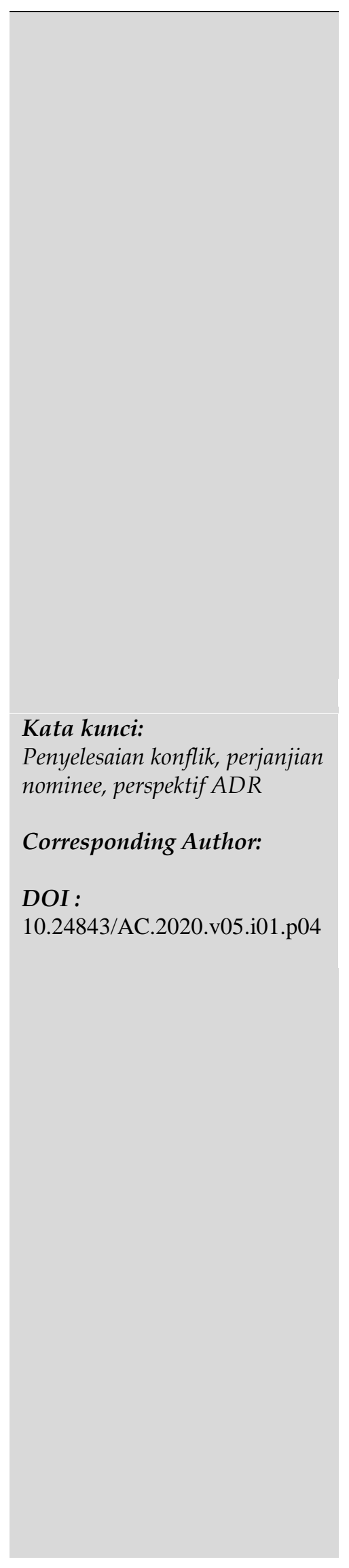

30 of 1999.

Settlement of conflicts due to the nominee agreement from the perspective of $A D R$ provides an opportunity for both parties to resolve their dispute peacefully. The agreement was registered with the district court, the latest being the implementation of a peace deed carried out by both parties in good faith. The results of the contents of the agreement that have been registered with the District Court have an executive legal force. A peace deed, like an ordinary verdict that can be asked for execution if one day one party does not obey it, cannot be compared and is final binding on both parties.

\begin{tabular}{l} 
Abstrak \\
\hline Indonesia sebagai Negara kepulauan \\
yang kekayaan alamnya telah diakui oleh \\
dunia Internasional sangat menarik minat \\
banyak wisatawan (warga negara asing). \\
Berbagai macam tujuan orang asing itu pada \\
saat melakukan kegiatannya di Indonesia, \\
mendorong keinginan orang asing untuk \\
mempunyai tempat tinggal di Indonesia. Orang \\
asing yang memilih untuk bertempat tinggal di \\
Indonesia dapat menimbulkan dampak positif \\
bagi perkembangan perekonomian di Indonesia \\
salah satunya dengan melakukan investasi di \\
Indonesia.
\end{tabular}

Adapun tujuan yang diharapkan dari penelitian ini adalah untuk mengetahui bagaimana penyelesaian konflik akibat perjanjian 
nominee dalam perspektif Alternatif Dispute Resolution disebut (ADR) dan Untuk memahami bagaimana kekuatan hukum penyelesaian konflik akibat perjanjian nominee melalui mediasi bagi para pihak yang bersengketa.

Penelitian ini mengenai penyelesaian sengketa hak milik atas tanah akibat perjanjian nominee antara Warga Negara Indonesia dengan Warga Negara Asing melalui mediasi dalam perspektif ADR. Jenis penelitian yang dipergunakan dalam penelitian adalah menggunakan penelitian hukum normatif yaitu lebih mengacu pada norma-norma hukum yang terdapat di dalam peraturan perundangundangan, peraturan pemerintah, UUPA, Pasal 58 UU No 48 Tahun 2009, dan UU No. 30 Tahun 1999.

Penyelesaian konflik akibat perjanjian nominee dalam perspektif ADR memberikan kesempatan bagi kedua belah pihak untuk menyelesaikan sengketanya secara damai. Kesepakatan tersebut didaftarkan ke pengadilan negeri, terakhir pelaksanaan akta perdamaian yang dilaksanakan oleh kedua belah pihak dengan itikad baik. Hasil isi kesepakatan yang sudah didaftarkan ke Pengadilan Negeri memiliki kekuatan hukum eksekutorial. Akta perdamaian seperti putusan biasa yakni dapat diminta eksekusi jika suatu saat nanti salah satu pihak tidak mentaatinya, tidak dapat dibanding 
dan bersifat final mengikat kedua belah pihak.

\section{Pendahuluan}

Indonesia sebagai Negara kepulauan yang kekayaan alamnya telah diakui oleh dunia Internasional sangat menarik minat banyak wisatawan (warga negara asing). Orang asing yang datang ke Indonesia mempunyai tujuan yang beranekaragam dan berkunjung dalam jangka waktu yang lama ataupun berkunjung dalam jangka waktu yang singkat. Berbagai macam tujuan orang asing itu pada saat melakukan kegiatannya di Indonesia, mendorong keinginan orang asing untuk mempunyai tempat tinggal di Indonesia. Orang asing yang memilih untuk bertempat tinggal di Indonesia dapat menimbulkan dampak positif bagi perkembangan perekonomian di Indonesia salah satunya dengan melakukan investasi di Indonesia.

Investasi yang dilakukan oleh orang asing di Bali tentu saja membutuhkan lahan atau tempat untuk menjalankan investasi, dalam Undangundang Nomor 5 Tahun 1960 tentang Peraturan Dasar Pokok-Pokok Agraria (selanjutnya disebut UUPA) mengatur hak milik atas tanah hanya boleh dimiliki oleh warga Indonesia (selanjutnya disebut WNI), kenyataannya dalam praktik warga asing (selanjutnya disebut WNA) tetap ingin memiliki hak atas tanah di Indonesia. Guna menyiasati hal tersebut maka dalam praktik dibuatkanlah nominee atas tanah sehingga dapat menguasai hak milik atas tanah. Perjanjian nominee merupakan suatu upaya untuk memberikan kemungkinan bagi warga asing memiliki hak milik atas tanah yang dilarang oleh Undang-Undang Pokok Agraria (UU Nomor. 5 Tahun 1960) selanjutnya disingkat UUPA adalah dengan jalan menggunakan kedok melakukan jual beli 
atas nama warga Indonesia, sehingga secara yuridis formal tidak menyalahkan peraturan. ${ }^{1}$

Hak milik menurut Pasal 20 ayat (1) UUPA menyatakan "Hak turuntemurun, terkuat dan terpenuh yang dapat dipunyain orang atas tanah dengan mengingat ketentuan pasal 6". Subjek-subjek yang berhak atas hak milik berdasarkan Pasal 20 dipertegas dalam Pasal 21 tersirat terdiri dari warga Indonesia, badan-badan hukum yang berkedudukan di Indonesia untuk hak milik.

Perjanjian nominee bukan untuk WNI dan WNA saja tetapi antara WNI dengan WNI juga yang tujuannya adalah untuk menghindari pajak dan untuk memperbanyak kekayaan. Persoalan yang sering muncul diawali dengan wanprestasinya salah satu pihak mengakibatkan kedua belah pihak bersengketa.

Penyelesaian sengketa perdata akibat salah satu pihak ingkar janji dicontohkan dengan dua kasus yaitu:

1. Putusan Nomor 787/Pdt.G/2014/PN.DPS

Kasus Posisi dimana Karpika Wati (WNI) selaku nominee melawan Alain Maurice Pons (WNA), status tanah hak milik WNI disewakan dalam jangka 25 tahun dan secara otomatis diperpanjang kembali untuk jangka waktu 3x25 tahun sehingga berakhir selambat-lambatnya tanggal 6-8-2107, Karpika Wati (WN)I merasa cemas dan sangat ketakutan apabila suatu saat penggugat akan diusir oleh Tergugat I yaitu Alain Maurice Pons (WNA).

2. Putusan No. 12/PDT/2014/PT.DPS

Kasus Posisi dimana Saito Hiromi (WNA) selaku penggugat yang menggugat WNI karena WNI telah menjual tanah sengketa, WNA menyatakan bahwa WNI melakukan perbuatan melawan 41okum,jual beli tanah yang dilakukan Tergugat I (Choirul Anam) dan Tergugat II (Suwito Hartoyo) cacat hukum.

${ }^{1)}$ I Wayan Werasmana Sancaya, 2010, Kekuatan Mengikat Perjanjian Nominee Dalam Penguasaan Hak Milik Atas Tanah, HIm.1 
Berdasarkan kedua kasus di atas, mengenai sengketa Hak Milik atas tanah akibat perjanjian nominee bagi WNA dikarenakan pihak WNA tetap ingin menguasai Hak Milik atas tanah di Indonesia, padahal Undang-Undang (selanjutnya disebut UU) secara tegas sudah mengatur WNA memiliki tanah dengan status hak pakai. Pasal 2 ayat (1) PP No. 103 Tahun 2015 yaitu “Orang asing dapat memiliki rumah untuk tempat tinggal atau hunian dengan hak pakai" sebelum terbitnya PP No. 103 Tahun 2015 banyak terjadi penyeludupan hukum dari perjanjian nominee maka terjadilah sengketa seperti kasus di atas disebabkan kontruksi awal sudah salah. Fakta di pengadilan negeri pada kasus bahwa WNA cenderung dirugikan. Pihak yang diposisi dirugikan tentu merasa tidak puas dan menganggap hakim tidak berlaku adil meskipun sudah sampai pada puncaknya di Mahkamah Agung.

Ketetapan Pasal 58 Undang-undang Nomor 48 Tahun 2009 tentang Kekuasaan Kehakiman (selanjutnya disebut UU No. 40 Tahun 2009) menyebutkan: “Upaya penyelesaian sengketa perdata dapat dilakukan di luar pengadilan negeri melalui arbitrase atau alternatif penyelesaian sengketa". Atas dasar tersebut, sangat memungkinkan penyelesaian sengketa perjanjian nominee hak milikatas tanah diselesaikan di luar Pengadilan dengan cara perdamaian untuk WNI dan WNA, sehingga penulis tertarik untuk meneliti mengenai “Penyelesaian konflik akibat perjanjian nominee dalam perspektif ADR.

\section{Metode Penelitian}

\section{A. Jenis Penelitian}

Penelitian ini mengenai penyelesaian sengketa hak milik atas tanah akibat perjanjian nominee antara Warga Negara Indonesia dengan Warga Negara Asing melalui mediasi dalam perspektif ADR. Jenis penelitian yang dipergunakan dalam penelitian adalah menggunakan penelitian hukum normatif yaitu lebih mengacu pada norma-norma hukum yang terdapat di dalam peraturan perundang-undangan, peraturan pemerintah, UUPA, Pasal 58 UU No 48 Tahun 2009, dan UU No. 30 Tahun 1999.

\section{B. Jenis Bahan Hukum}


Jenis bahan hukum yang digunakan dalam penelitian ini yaitu:

1. Bahan Hukum Primer

Jenis bahan hukum yang digunakan penulisan dalam penelitian ini menggunakan bahan hukum primer yakni bahan-bahan hukum yang mengikat yakni:

a. Undang-undang Dasar Republik Indonesia Tahun 1945

b. Kitab Undang-undang Hukum Perdata (KUHPerdata).

c. Undang-undang Nomor 5 Tahun 1960 tentang Peraturan Dasar Pokok-Pokok Agraria.

d. Undang-undang Nomor 48 Tahun 2009 tentang Kekuasaan Kehakiman.

e. Undang-undang Nomor 30 Tahun 1999 tentang Arbitrase dan Alternatif Penyelesaian Sengketa.

f. PERMA Nomor 1 Tahun 2016 tentang Prosedur Mediasi di Pengadilan.

g. Peraturan Pemerintah Nomor 103 Tahun 2015 tentang Pemilikan Rumah Tempat Tinggal Atau Hunian Oleh Orang Asing Yang Berkedudukan di Indonesia

2. Bahan Hukum Sekunder

Jenis bahan hukum yang digunakan penulis dalam penelitian ini menggunakan bahan hukum sekunder yang bersumber dari pendapat para pakar hukum tentang teori kepastian hukum, teori keadilan, teori kehendak, konsep-konsep hukum dan asas-asas hukum khususnya yang mengenai penyelesaian konflik akibat perjanjian nominee antara WNI dengan WNA dengan perspektif ADR yang diperoleh dari buku-buku, jurnal dan sumber dari internet.

\section{Teknik Pengumpulan Bahan Hukum}

Teknik pengumpulan bahan hukum yang digunakan penulis dalam penelitian ini yaitu teknik pengumpulan bahan hukum sekunder dilakukan 
dengan penelaahan bahan hukum primer putusan-putusan hakim baik sekunder seperti buku-buku tentang bentuk-bentuk penyelesaian sengketa, jurnal mengenai perjanjian-perjanjian nominee serta membuat catatancatatan baik berupa kutipan pendapat para sarjana seperti teori kepastian hukum, teori keadilan, teori kehendak yang berkaitan dengan permasalahan yang akan diteliti.

\section{Teknik Analisis Bahan Hukum}

Teknik analisis bahan hukum yang digunakan penulis adalah menggunakan teknis menganalisis bahan hukum primer dan bahan hukum sekunder yaitu dengan menguraikan bahan-bahan hukum yang sudah diperoleh, dikumpulkan sesuai dengan yang sudah diperoleh selanjutnya dikaitkan dengan teori-teori yang diperoleh kemudian dianalisis, disusun secara sistematis dan mendapatkan kesimpulan yang berkaitan dengan penelitian ini.

\section{Hasil Dan Pembahasan}

\section{A. Penyelesaian Konflik Akibat Perjanjian Nominee Dalam Perspektif ADR} (Alternatif Dispute Resolution)

Penyelesaian sengketa litigasi di pengadilan berdasarkan Pasal 3 ayat (1) PERMA No. 1 Tahun 2016 adalah “Setiap Hakim, Mediator, Para Pihak dan/atau kuasa hukum wajib mengikuti prosedur penyelesaian sengketa melalui mediasi", jadi sebelum para pihak melanjutkan berperkara terlebih dahulu para pihak diwajibkan melangsungkan mediasi di pengadilan. Pengertian mediasi sendiri dapat dijumpai dalam Pasal 1 angka 1 PERMA No. 1 Tahun 2016 "mediasi adalah cara penyelesaian sengketa melalui proses perundingan untuk memperoleh kesepakatan para pihak dengan dibantu oleh mediator."

Berdasarkan Pasal 6 ayat (1), (2), dan (3) UU No. 3 Tahun 1999 penyelesaian sengketa Hak Milik atas tanah akibat perjanjian nominee yang diselesaikan melalui non litigasi mediasi perspektif ADR. Kesempatan bagi 
para pihak sengketanya diselesaikan dengan perspektif ADR dimana ketentuan tersebut pada dasarnya menegaskan bahwa asas musyawarah mufakat diutamakan terlebih dahulu supaya menghasilkan penyelesaian yang saling menguntungkan (win-win solution).

Teori kehendak ADR menjamin kerahasian kedua belah pihak berbeda halnya dengan penyelesaian melalui menurut B.M.W NieskensIsphording yang dikutip oleh Herlien Budiono, "faktor yang menentukan adanya perjanjian adalah kehendak" $^{2}$ penyelesaian sengketa melalui mediasi perspektif ADR dipilih atas dasar kehendak kedua belah pihak yaitu WNI dan WNA. Kedua belah pihak memiliki kehendak yang sama karena ingin berdamai untuk menyelesaikan sengketa diantara mereka. Kesepakatan yang mereka putuskan merupakan pilihan atas kehendak mereka. Proses mediasi dalam perspektif ADR dimulai dengan adanya 4 (empat) tahap, yaitu pramediasi, pelaksanaan mediasi, penutupan mediasi dan pelaksanaan akta perdamaian ${ }^{3}$

1. Pramediasi

Asas konsensualitas mengandung arti bahwa perjanjian terjadi sejak adanya kata sepakat antara pihak-pihak mengenai pokok perjanjian. ${ }^{4}$ Keterkaitan dengan asas konsesualitas bahwa sejak saat WNI dengan WNA bersepakat untuk menyelesaikan sengketa melalui mediasi perspektif ADR menunjuk seorang mediator yang dapat dipercaya mampu untuk menyelesaikan sengketa. Sepakat artinya sudah kehendak dari pihak WNI dan WNA untuk melaksanakannya melalui mediasi perspektif ADR. Pramediasi, mediator memulai untuk melakukan identifikasi kepada kedua belah pihak yang bersengketa

\footnotetext{
${ }^{2)}$ Budiono, Harlien, 2010, Ajaran Umum Hukum Perjanjian dan Penerapannya di Bidang Kenotariatan, Citra Aditya, hlm. 77.

3) Candra Irawan, 2010, Aspek Hukum dan Mekanisme Penyelesaian Sengketa di Luar Pengadilan (Alternatif Dispute Resolution) di Indonesia, Mandar Maju, hlm. 44

${ }^{4)}$ Saija Ronald dan F.X.V Roger, 2016, Buku Ajar Hukum Perdata, Deepublish, Yogyakarta, hlm. 135
} 
dengan menganalisis sengketa dan memperkenalkan diri sebagai pihak ketiga yang ditunjuk sebagai mediator.

2. Pelaksanaan Mediasi

Pelaksanaanya mediasi setelah menunjuk seorang mediator pada ketentuan Pasal 6 ayat (6) UU No. 30 Tahun 1999 “Usaha penyelesaian sengketa atau beda pendapat melalui mediator sebagaimana dimaksud dalam ayat (5) dengan memegang teguh kerahasiaan, dalam waktu paling lama 30 (tiga puluh) hari harus tercapai kesepakatan dalam bentuk tertulis yang ditandatangani oleh semua pihak yang terkait." Proses pelaksanaan mediasi yakni :

a. Mediator memulai mediasi dengan beberapa kegiatan yakni memperkenalkan diri dan mengenal tim dari para pihak baik pihak WNI maupun WNA, menawarkan aturan main tata tertib dan tata cara pelaksanaan mediasi perspektif ADR, meminta kepada kedua belah pihak agar tetap mentaati aturan selama proses mediasi berlangsung. Asas itikad baik memiliki peran yang sangat penting dalam membuat perjanjian. Ketentuan ini sesuai dengan Pasal 1338 KUHPerdata yang menyatakan bahwa perjanjian harus dilaksanakan dengan itikad baik. ${ }^{5}$

b. Selama pelaksanaan mediasi pihak WNI dan WNA harus terbuka, jujur dan saling percaya dalam memberikan pernyataan masingmasing tidak melakukan tipu daya terhadap keadaan sebenarnya yang membuat salah satu pihak wanprestasi.

c. Proses negosiasi antara pihak WNI dengan pihak WNA. Selama berlangsungnya negosiasi para pihak saling tawar-menawar mengenai hal-hal yang akan mereka mungkinkan untuk mencapai kesepakatan. Mediator disini tetap memberikan masukan dan saran berbagai pilihan jalan keluar dengan diterbitkannya PP No. 103

${ }^{5)}$ Supianto, 2015, Hukum Jaminan Fidusia Prinsip Publisitas Pada Jaminan Fidusia, Garudhawaca, hlm. 55 
Tahun 2015 bahwa dengan status hak pakai, WNA dapat memiliki tanah di Indonesia. Pasal 6, Pasal 7 dan Pasal 8 PP No. 103 Tahun 2015 memberikan waktu dan dapat diperpanjang selama orang asing masih memiliki izin tinggal di Indonesia. Mediator memberikan arahan dengan diterbitkannya PP No. 103 Tahun 2015 dibuatkannya kontruksi yaitu:

a) Membatalkan akta yang sudah dibuat dulu yang terkait dengan perjanjian nominee.

b) Dibuat hak pakai untuk orang asing berdasarkan ketentuan PP No. 103 Tahun 2015. Mediator selanjutnya mengembangkan pilihan mereka dan menyusun konsep tersebut bisa sesuai untuk dijadikan kesepakatan. Asas kebebasan berkontrak pada ketentuan Pasal 1338 ayat (1) yang berbunyi "Semua persetujuan yang dibuat secara sah berlaku sebagai undang-undang bagi mereka yang membuatnya." Keterkaitan dengan asas kebebasan berkontrak yaitu kedua belah pihak bebas untuk menentukan pilihan terkait apa saja isi dan bunyi kesepakatan mereka, tidak adanya tekanan dan paksaan diantara keduanya.

3. Penutupan Mediasi

Ketentuan Pasal 6 ayat (7) "Kesepakatan penyelesaian sengketa atau beda pendapat secara tertulis final dan mengikat para pihak untuk dilaksanakan dengan itikad baik serta wajib didaftarkan di Pengadilan Negeri dalam waktu paling lama 30 (tiga puluh) hari sejak penandatanganan." Hasil kesepakatan ditandatangani oleh kedua belah pihak yakni jika WNI dengan WNA sepakat untuk berdamai dibuat kontruksi dengan membatalkan akta yang dibuat oleh kedua belah pihak, dibuatkan hak untuk orang asing berdasarkan ketentuan PP No. 103 Tahun 2015 dan didaftarkan ke pengadilan apakah sudah sesuai dengan aturan perundang-undangan atau tidak. 
4. Pelaksanaan Akta Perdamaian

Ketentuan Pasal 6 ayat (8) "Kesepakatan penyelesaian sengketa atau beda pendapat sebagaimana dimaksud dalam ayat (7) wajib diselesaikan dalam waktu paling lama 30 (tiga puluh) hari sejak pendaftaran." Kesepakatan perdamaian yang sudah didaftarkan adanya kepastian hukum bagi kedua belah pihak, baik pihak WNI dan pihak WNA.

Teori keadilan menurut Potter Stewart menyatakan "Fairness is what justice really is"6, yang menghendaki bahwa kejujuran itulah inti dari keadilan yang sesungguhnya esensinya pilihan kedua belah pihak melalui mediasi perspektif ADR adalah bila seseorang baik pihak WNI atau WNA jujur akan kesalahannya dia harus berani mengungkap bahwa memang saya salah maka pihak lain pun harus mengakui kesalahannya kalau sudah sama-sama mengakui kesalahan disitulah muncul keadilan yang sesungguhnya dan bersama-sama menentukan kesepakatan mereka.

Keadilan yang sama dengan penyampaian yang berbeda terungkap dari teori keadilan menurut Jeremy Bentham menyatakan "the greatest good of the greatest number"7artinya kebaikan yang terbesar dari jumlah yang terbanyak, dari proses penyelesaian melalui mediasi perspektif ADR mendapatkan sebuah kebaikan terbesar memilih menyelesaikan sengketa hak milik atas tanah akibat perjanjian nominee yang dimana keduanya bersepakat untuk memilih atau menunjuk mediator karena kedua belah pihak baik WNI dan WNA bersedia mengungkapkan segalanya baik keburukan dan kebaikan sebelum perjanjian nominee itu menjadi sengketa diantara mereka. Pihak WNI dan WNA mendapatkan suatu keadilan karena bersepakat dengan dibuatkannya kontruksi sesuai dengan PP No. 103 Tahun 2015

\footnotetext{
${ }^{6)}$ Ali, Achmad, 2009, Menguak Teori Hukum (Legal Theory) dan Teori Peradilan (Judicial Prudence), Prenadamedia Group, hlm. 219.

${ }^{7)}$ Gie, The Liang, 1997, Teori-Teori Keadilan, Super Yogyakarta. HIm. 30.
} 
menggunakan hak pakai jadinya membatalkan akta yang dibuat dulu terkait dengan perjanjian nominee. Menyadari bahwa WNA tidak dapat menguasai hak milik atas tanah.

B. Kekuatan Hukum Penyelesaian Konflik Akibat Perjanjian Nominee Dalam Perspektif ADR (Alternatif Dispute Resolution).

Mediasi dalam perspektif ADR dalam ketentuan UU No. 30 Tahun 1999 yang sudah dilaksanakan oleh kedua belah pihak yang dibantu oleh seorang mediator atas kesepakatan mereka. Hasil dari kesepakatan perdamaian memberikan kepastian hukum dimana mereka bersepakat untuk membatalkan akta yang dibuat dulu sebelum terjadinya sengketa, dengan dibuatkan hak untuk orang asing dengan hak pakai dari kesepakatan mereka adanya kekuatan hukum menjamin hak dari WNA sehingga dapat memiliki tanah di Indonesia. Keseluruhan isi dari kesepakatan mereka yang didaftarkan ke pengadilan negeri yang disebut akta perdamaian memiliki kekuatan hukum eksekutorial.

Teori kepastian hukum menurut Jan Michiel Otto menyatakan kepastian hukum "reele rechtzekerheid in ontwikkelingslanden" kepastian hukum yang nyata di Negara berkembang. ${ }^{8}$ Jan Michiel Otto memberikan batasan-batasan yakni keterkaitan dengan kekuatan hukum dari mediasi, pertama, tersedianya aturan-aturan yang mudah diperoleh seperti penyelesaian sengketa melalui mediasi perspektif ADR yang merupakan pilihan dari kedua belah pihak untuk menyelesaikan secara damai. Kedua, instansi-instansi penguasa (pemerintah) menerapkan aturan-aturan yang mana pelaksanaan mediasi perspektif ADR yang dibantu oleh pihak ketiga yaitu seorang mediator yang ditunjuk oleh kedua belah pihak dan tunduk terhadap aturan tata cara mediasi. Ketiga, kedua belah pihak menyesuaikan aturan-aturan mediasi dan sesuai dengan kehendak untuk melaksanakan mediasi perspektif ADR. Keempat, hakim-hakim menerapkan aturan secara

${ }^{8)}$ Jan Michiel Otto, Kepastian Hukum di Negara Berkembang, Komisi Hukum Nasional Republik Indonesia (KHN-RI) 
adil, hasil penyelesaian sengketa secara tertulis berupa kesepakatan didaftarkan ke pengadilan negeri guna mendapatkan kekuatan hukum eksekutorial. Berlaku adil bagi kedua belah pihak dilaksanakan melalui mediasi perspektif ADR. Kelima, keputusan secara kongkret dilaksanakan pada akta perdamaian kedua belah pihak.

Teori kepastian hukum menurut Sudikno Mertokusumo yaitu “jaminan bahwa hukum dijalankan, bahwa yang berhak menurut hukum dapat memperoleh haknya dan putusan dapat dilaksanakan" 9 hasil mediasi yaitu "win-win solution"yang artinya saling menguntungkan kedua belah pihak, kepastian hukum dengan menggunakan hak pakai terhadap kesepakatan perdamaian yang secara tertulis didaftarkan ke pengadilan negeri. Akta perdamaian yang memiliki kekuatan hukum eksekutorial adanya jaminan bahwa hukum dijalankan, karena mereka bersepakat untuk membatalkan akta yang dibuat sebelum mereka bersengketa, kedua belah pihak merasa mendapatkan keadilan mendapatkan haknya sebagaimana isi dalam putusan akta perdamaian tersebut dan melaksanakan kewajibannya.

\section{4. Kesimpulan}

\section{A. Kesimpulan}

Berdasarkan pembahasan terhadap penulisan ini maka dapat disimpulkan sebagai berikut:

1. Penyelesaian konflik akibat perjanjian nominee dalam perspektif ADR memberikan kesempatan bagi kedua belah pihak untuk menyelesaikan sengketanya secara damai. Ketentuan UU No. 30 Tahun 1999 tentang Arbitrase dan Alternatif Penyelesaian Sengketa Mediasi melalui ADR dari tahap pramediasi mediator ditunjuk oleh kedua belah pihak. Proses pelaksanaan mediasi kedua belah dapat menuangkan pendapat dan saling tawar menawar tetap diarahkan oleh mediator jika berdasarkan PP No. 103 Tahun 2015 mengatur orang asing bisa memiliki tanah dengan status hak pakai, pada proses penutupan mediasi

\footnotetext{
${ }^{9}$ Mertokusumo Sudikno, 2007, Mengenal Hukum Suatu Pengantar, Liberty, hlm. 160.
} 
dilakukan penandatangan kesepakatan perdamaian secara tertulis yang menyatakan pilihan kedua belah pihak untuk menentukan kesepakatan dengan menggunakan hak pakai untuk orang asing yang dibuat di PPAT setelah pelaksanaan akta perdamaian. Kesepakatan tersebut didaftarkan ke pengadilan negeri, terakhir pelaksanaan akta perdamaian yang dilaksanakan oleh kedua belah pihak dengan itikad baik.

2. Hasil isi kesepakatan yang sudah didaftarkan ke Pengadilan Negeri memiliki kekuatan hukum eksekutorial. Sudikno Mertokusumo menyatakan kekuatan hukum eksekutorial "kekuatan untuk dilaksanakannya apa yang diterapkan dalam putusan itu secara paksa oleh alat-alat negara." Kedua belah sudah terikat oleh hak dan kewajiban, sebagai pihak WNA mendapatkan haknya sebagai orang asing dengan menggunakan hak pakai, sedangkan pihak WNI sebagai yang dipinjam namanya terbebas dari tanggungjawabnya secara hukum sebagai nominee. Akta perdamaian seperti putusan biasa yakni dapat diminta eksekusi jika suatu saat nanti salah satu pihak tidak mentaatinya, tidak dapat dibanding dan bersifat final mengikat kedua belah pihak.

\section{B. Saran}

Adapun saran dari penulis yaitu suatu sengketa dalam dunia bisnis pastinya tidak diinginkan oleh siapapun, tetapi jika terjadinya sengketa hendaknya pilihan penyelesaian sengketa melalui mediasi perspektif ADR menjadi suatu alternatif penyelesaian sengketa yang banyak diminati oleh pelaku bisnis. Sebaiknya, WNA/orang asing menggunakan hak pakai jika ingin berivestasi di Indonesia khususnya di Bali. Pemerintah haruslah bersikap tegas terhadap yang masih menggunakan perjanjian nominee agar peranan investasi mendorong pertumbuhan ekonomi yang optimal di Indonesia. 


\section{DAFTAR PUSTAKA}

Ali, Achmad, 2009, Menguak Teori Hukum (Legal Theory) dan Teori Peradilan (Judicial Prudence), Prenadamedia Group, Jakarta.

Budiono, Harlien, 2010, Ajaran Umum Hukum Perjanjian dan Penerapannya di Bidang Kenotariatan, Citra Aditya, Bandung.

Gie, The Liang, 1997, Teori-Teori Keadilan, Super Yogyakarta, Yogyakarta.

Irawan, Candra, 2010, Aspek Hukum dan Mekanisme Penyelesaian Sengketa di Luar Pengadilan (Alternatif Dispute Resolution) di Indonesia, Mandar Maju, hlm. 44

Mertokusumo Sudikno, 2007, Mengenal Hukum Suatu Pengantar, Liberty, Yogyakarta.

Otto, Jan Michiel, Kepastian Hukum di Negara Berkembang, Komisi Hukum Nasional Republik Indonesia (KHN-RI)

Saija Ronald dan F.X.V Roger, 2016, Buku Ajar Hukum Perdata, Deepublish, Yogyakarta, hlm. 135

Supianto, 2015, Hukum Jaminan Fidusia Prinsip Publisitas Pada Jaminan Fidusia, Garudhawaca, hlm. 55

\section{PERATURAN PERUNDANG-UNDANGAN}

Undang-Undang Dasar Republik Indonesia Tahun 1945.

Kitab Undang-Undang Hukum Perdata (KUHPerdata).

Undang-Undang No. 5 Tahun 1960 tentang Peraturan Dasar Pokok-Pokok Agraria.

Undang-Undang No. 48 Tahun 2009 tentang Kekuasaan Kehakiman.

Undang-Undang No. 30 Tahun 1999 tentang Alternatif Penyelesaian Sengketa.

PERMA No. 1 Tahun 2016 Tentang Prosedur Mediasi di Pengadilan.

Peraturan Pemerintah Nomor 103 Tahun 2015 tentang Pemilikan Rumah

Tempat Tinggal Atau Hunian Oleh Orang Asing Yang Berkedudukan di Indonesia.

\section{JURNAL}

Sancaya, I Wayan Werasmana, 2010, Kekuatan Mengikat Perjanjian Nominee

Dalam Penguasaan Hak Milik Atas Tanah, Program Pasca Sarjana

Universitas Udayana, Bali.

http:/ / ejournal.uajy.ac.id/7935/3/MIH201897.pdf, hlm. 20, diakses pada desember 2017, pukul. 20.30 